\title{
Weeds in wheat crop: weed whole plants nutrient concentration and uptake under fertilizer application and irrigation frequencies
}

\author{
Muhammad Ayub Babar ${ }^{1 *}$, Ajmal Khan², Sher Azam³ Ikramullah $^{4}$, \\ Muhammad Arif ${ }^{5}$ and Sarfaraz Hussain ${ }^{6}$ \\ 1. Directorate of Agriculture Research Fodder Crops ARI Sariab Quetta-Pakistan \\ 2. Balochistan Agriculture College Quetta-Pakistan \\ 3. Directorate of Agriculture Research Cereal Crops ARI Sariab Quetta-Pakistan \\ 4. Directorate of Agriculture Research Usta Muhammad-Pakistan \\ 5. Directorate of Agriculture Research (Pulses) ARI Sariab Quetta-Pakistan \\ 6. Agriculture Extension Quetta-Pakistan \\ *Corresponding author's email: $\underline{\text { mhdayubbabar@gmail.com }}$ \\ Citation
}

Muhammad Ayub Babar, Ajmal Khan, Sher Azam, Ikramullah, Muhammad Arif and Sarfaraz Hussain. Weeds in wheat crop: weed whole plants nutrient concentration and uptake under fertilizer application and irrigation frequencies. Pure and Applied Biology. Vol. 8, Issue 2, pp1724-1735. http://dx.doi.org/10.19045/bspab.2019.80116

Received: 06/12/2018

Revised: 21/06/2019

Accepted: $27 / 06 / 2019$

Online First: 30/06/2019

\section{Abstract}

Weeds infestation in cereal crops is the one of main biotic stresses because in its presence crop cannot utilize effectively the available resources like moisture, nutrients and sun light. So, this study was aimed to quantify weeds trait and weed whole plants nutrient concentration and uptake in weed infested plots under wheat crop. Under the two separate experiments, the fertilizer rates and irrigation frequencies were integrated with weed management practices (data not provided) but weeds were allowed to grow in the control plots and the data were collected only from these weed infested plots analysed using descriptive statistics. Thirteen weeds species were recorded. Under NPK fertilizer application, maximum weed biomass $\left(5916.7 \mathrm{~kg} \mathrm{ha}^{-1}\right)$, weed density $\left(166.67 \mathrm{~m}^{-2}\right)$, weed frequency $(6.5 \%)$, weed whole plants NPK concentration $(1.64,0.23$ and $1.80 \%)$ and NPK uptake $\left(101.15,14.36\right.$ and $\left.112.25 \mathrm{~kg} \mathrm{ha}^{-1}\right)$ were recorded in plot when 205-110-50 kg NPK ha-1 was applied in weed infested plots. In case of irrigation frequencies, higher maximum weed biomass $\left(5487.3 \mathrm{~kg} \mathrm{ha}^{-1}\right)$, weed density $\left(163.0\right.$ weeds $\left.\mathrm{m}^{-2}\right)$, weed frequency $(7.50 \%)$, weed whole plants NPK concentration $(1.24,0.28$ and $1.86 \%)$ and NPK uptake (63.5, 12.91 and $90.1 \mathrm{~kg} \mathrm{ha}^{-1}$ ) were found in plot when 6 irrigations were applied. while positive and significant correlation was observed between weed biomass and weed whole plants NPK upake under both experiment. From this study it was inferred that the applied fertilizer and irrigation gave more benefits to weed at the cost of wheat because weeds are more competitor than crop.

Keywords: Fertilizer; Irrigation frequencies; Weeds; Wheat; Weed crop competition; Weeds nutrients uptake

\section{Introduction}

Moisture regimes are one of the important factors affecting growth and yield of crop substantially. Judicious use of irrigation frequencies for wheat crop production is very essential as it ensures better grain yield 
by increasing the overall growth and yield components [1-3]. Unavailability of sufficient water across the world is the primary constraint for wheat production [4]. Many scientific literature revealed that under moisture stress condition the performance of wheat showed some degree of correlation with yield potential and such growth performance of wheat under drought condition has become the priority area of research $[5,6]$.

The use of NPK fertilizer in balanced form proved better for suppressing weed proliferation which is due to efficient light interception by wheat and resultantly increased wheat photosynthetic activities over weed [7] but the application of PK fertilizer increased weed density and diversity rather than wheat. In another experiment conducted by El-Metwally et al. [8] revealed that all types weeds in respect of their frequency and density were increased by greater $\mathrm{N}$ rate of $60 \mathrm{~kg} \mathrm{fed}^{-1}$ and reduced by $15 \mathrm{~N} \mathrm{~kg} \mathrm{fed}^{-1}$. Weed crop competition under organic and conventional farming system revealed that corn yield remain same in both of them with higher weed biomass in organic system [9]. It demonstrated that infested weeds in organic system did not affect corn yield due to its tolerance against weeds.

There are evidences that fertilizer management can affect both crop and weed growth but such management must favor crop growth rather than weeds. The selection of fertilizer can improve crop competitiveness against weeds $[10,11]$ and particularly the application of $\mathrm{N}$ fertilizer as a function of crop competitiveness reliance on weed species existing in crop community. Blackshaw and Randall [10] who tested four weed species such as Persian darnel, Russian thistle, redroot pigweed and wild oat across three $\mathrm{N}$ rates (60, 120 and $240 \mathrm{~N} \mathrm{mg} \mathrm{kg}{ }^{-1}$ soil), noticed that two weed species (Persian darnel and
Russian thistle) did not respond to the applied $\mathrm{N}$ rates but other two species performed well on higher $\mathrm{N}$ rates. In another study, Blackshaw et al. [12] evaluated the effect of different $\mathrm{N}$ rates $(0,40,80,120$, 180 and $240 \mathrm{mg} \mathrm{kg}^{-1}$ ) against growth response of 23 weed along with wheat and canola as control species under controlled conditions. The majority of weed species responded same like wheat or canola or greater than them with respect to root and shoot biomass. At lower soil $\mathrm{N}$ level, all the species including crops recovered more than $80 \% \mathrm{~N}$ but at higher $\mathrm{N}$ level, the weed $\mathrm{N}$ uptake was higher as compared to crops. From this study they inferred that soil fertility affects the competitive interaction between crops and weed and high response of some weed to $\mathrm{N}$ can be used in formulation of fertilizer recommendation methods to enhance crop competitiveness against weed. Keeping in view the importance of chemical fertilizer and irrigation in wheat production and the deteriorative effect of weed infestation on wheat, the present study was conducted to assess the weeds traits and weed whole plants nutrient concentration and uptake in weed infested plots under the influence of NPK fertilization and irrigation frequencies on wheat crop.

\section{Materials and methods}

Weeds were allowed to grow in the control plots under the already established experiments encompassing the integrative effect of NPK fertilizer application and irrigations frequencies along with weed management practices on growth and yield of wheat (data not provided). Under the two separate experiments, the fertilizer rates were integrated with weed management practices in one experiment while irrigation frequencies were integrated with weed management practices in the second experiment. The treatments detail of these experiments were: 


\author{
Fertilizer treatments \\ $\mathrm{F} 1=0-0-0 \mathrm{NPK} \mathrm{kg} \mathrm{ha}^{-1}$ \\ $\mathrm{F} 2=100-80-50$ NPK kg ha ${ }^{-1}$ \\ $\mathrm{F} 3=135-90-50$ NPK kg ha ${ }^{-1}$ \\ F4 $=170-100-50$ NPK kg ha-1 \\ F5 $=205-110-50$ NPK kg ha-1 \\ Weed management techniques \\ $\mathrm{W} 1=$ No weeding \\ W2 = Herbicides application: \\ $\mathrm{W} 3$ = Hand hoeing (after first and second \\ irrigation) \\ W4 = Allelopathic weed control (Sunflower \\ extract) \\ Irrigation frequencies \\ $\mathrm{I}_{1}=3$ irrigations \\ $\mathrm{I}_{2}=4$ irrigations \\ $\mathrm{I}_{3}=5$ irrigations \\ $\mathrm{I}_{4}=6$ irrigations
}

The data pertaining to nutrient accumulation and uptake of weeds were gathered from plots of both fertilizer treated and irrigated plots as per treatments where weeds were let grown (no weeding). In this study, the competition between weeds and wheat crop for nutrients were studied as a component of the two experiments. In these established experiments, weeds flora, frequency and weed density were recorded in no weeding plots.

\section{Weed flora}

Total number of weed species were counted in a unit area.

\section{Weeds frequency}

The frequency of occurrence of weeds was calculated using a formula [13].

Frequency $(\%)=\frac{\text { total no. of weed species } \mathrm{m}^{-2}}{\text { Weed density } \mathrm{m}^{-2}} \times 100$

\section{Weed density}

The density of weeds was calculated as arithmetical means (plants $\mathrm{m}^{-2}$ ).

Weed biomass ( $\left.\mathrm{kg} \mathrm{ha}^{-1}\right)$

The total number of weeds $\mathrm{m}^{-2}$ were collected, air dried and determined their biomass in $\mathrm{kg}$ and then converted them into $\mathrm{kg} \mathrm{ha}^{-1}$.

\section{Soil analysis}

The soil of both experimental sites were analysed before the installation of the experiment and analysed for soil texture, $\mathrm{pH}$, electrical conductivity (EC), organic matter and AB-DTPA (ammonium bicarbonate-diethylenetriaminepentaacetic acid) extractable phosphorus (P) and potassium $(\mathrm{K})$. Soil mechanical analysis was carried by hydrometer method as described by Bouyoucos [14], $\mathrm{pH}$ and EC were measured in 1:5 soil and water suspension $[15,16]$ and organic matter by oxidizing method [17, 18]. While, AB-DTPA extraction solution was used for extracting $\mathrm{P}$ and $K$ [19]. In the clear filtrate of AB-DTPA soil extract, phosphorus was determined on Spectrophotometer at $880 \mathrm{~nm}$ wavelength and potassium on Flame Photometer. Total nitrogen contents of soil was determined by Kjeldhal method [20].

\section{Plant analysis}

Weed whole plants at flowering stage were collected, decontaminated with tap water and then immediately washed with distilled water [21]. These samples were then oven dried at $80^{\circ} \mathrm{C}$ for 48 hours, grinded and then stored at $4^{\circ} \mathrm{C}$ for target analysis. Weighed $0.5 \mathrm{~g}$ of the prepared plant sample and wet digested using hot sulfuric acid with repeated additions of $30 \%$ hydrogen peroxide $\left(\mathrm{H}_{2} \mathrm{O}_{2}\right)$ until the digestion was completed, then this digest was used for the determination of total nitrogen, phosphorus and potassium [22]. For phosphorus, Pipetted $10 \mathrm{ml}$ of the digest into a $100 \mathrm{ml}$ volumetric flask, added $10 \mathrm{ml}$ ammoniumvanadomolybdate and diluted the solution with Deionized water upto the mark [23]. Then, read the absorbance of the blank, 
standards, and samples after 30 minutes at 410-nm wavelength on Spectrophotometer. The potassium in the digest was determined directly by Flame Photometer [24]. Total nitrogen was determined by Kjeldhal method [25].

\section{Nutrient uptake (kg ha-1)}

Nutrient uptake in weeds under the influence of NPK fertilizer application and irrigation frequencies were determined as under:

\section{N-uptake}

Nitrogen uptake was calculated through TDM $\mathrm{x}$ N concentration in plant/(100).

\section{P-uptake}

Phosphorus uptake was observed through TDM x P concentration in plant / (100).

\section{K-uptake}

Potassium uptake was observed through TDM $\mathrm{x}$ K concentration in plant / (100).

The data regarding nutrient accumulation and uptake in weeds were subjected to descriptive statistics using computer software Statistix 8.1 (Math Soft Inc., Cambridge, MA, USA). Actually, mean of three replicates of weed control plot (no weeding) under NPK fertilizer application and irrigation frequencies as separate experiments and then compared the competitive ability of wheat against weeds for $\mathrm{N}, \mathrm{P}$ and $\mathrm{K}$ nutrient.

\section{Results}

Before the conduction of experiments, the composite soil samples were collected from two sites and analysed for soil physicochemical properties (Table 1). The soil of both sites were sandy clay loam in texture having soil $\mathrm{pH} 8.03$ (site-I) and 8.04 (site-II) and electrical conductivity of 1.62 $\mathrm{dSm}^{-1}$ (site-I) and $2.06 \mathrm{dSm}^{-1}$ (site-II) which mean that the soil of both sites were alkaline in nature and non-saline. While, soil organic matter contents $(0.59$ and $0.61 \%)$, total nitrogen $(0.029$ and $0.031 \%)$ and AB-DTPA extractable phosphorus (2.77 and $2.52 \mathrm{mg}$ $\mathrm{kg}^{-1}$ ) were low. However, the available potassium in soil of both sites was $124.8 \mathrm{mg}$ $\mathrm{kg}^{-1}$ and $130.3 \mathrm{mg} \mathrm{ka}^{-1}$ which was in high range.

This study represent data collected in control plots (no weeding) of both experiments of NPK Fertilizer application and irrigation frequencies of wheat crop integrated with weed management sciences. In control plot weeds were allowed to grow in wheat crop which also received NPK fertilizer and irrigation frequencies per treatments. The data regarding weeds flora in no weeding pots (weed control) revealed that in both experiments of wheat crop thirteen weeds species were recorded which were comprised of Bhatur (local name)-Milk weed (Launaea nodicavlis), Chabbar (local name)-Lawn rass/Bermuda grass (Cynodon dactylon (L.) Pers), Dhumbi gah (local name)-Wheat grass/Canary grass (Phalaris minor (Retz.), Gider gah (local name)-Fox weed (Conyza stricta), Kalar gah (local name)-Corn spury (Spergula arvensis (F.), Jangli palak (local name)-Sheep sorrel/Dock (Rumex dentatus (L.), Jangli jai (local name)-Wild oat (Avena fatua (L.), Jhil (local name)-Goose foot/Lambs' quarter (Chenopodium album), Kurand (local name)-Nettle leaf (Chenopodium murale (L.), Madhano (local name)-Goose grass (Eleusine indica/aegyptica), Naro (local name)-Field bind weed (Convolvulus arvensis (L.), Nili booti (local name)- Red Chick weed (Anagallis arvensis (L.) and Sinjh (local name)-White sweet clover (Melilotus alba (L.).

Maximum weed biomass (5487.3 $\mathrm{kg} \mathrm{ha}^{-1}$ ) and weed density (163 weeds $\mathrm{m}^{-2}$ ) were noted in when 6 irrigations were applied to wheat crop while higher weed frequency of $8.66 \%$ was noticed in minimum irrigated plot i.e. where wheat crop irrigated with 3 irrigations (Table 2). Similarly, higher fertilizer rates also resulted in greater weed biomass, density and frequency (Table 2). 
Table 1. Soil physicochemical properties of the experimental sites

\begin{tabular}{|c|c|c|c|}
\hline \multirow[b]{2}{*}{ Soil properties } & \multirow[b]{2}{*}{ Unit } & \multicolumn{2}{|c|}{ Result } \\
\hline & & $\begin{array}{c}\text { Experimental site-I (NPK } \\
\text { Fertilization) }\end{array}$ & $\begin{array}{c}\text { Experimental site-II } \\
\text { (irrigation frequencies) }\end{array}$ \\
\hline Sand & $\%$ & 53.0 & 53.3 \\
\hline Silt & $\%$ & 21.3 & 17.1 \\
\hline Clay & $\%$ & 25.7 & 29.6 \\
\hline Textural Class & & Sandy clay loam & Sandy clay loam \\
\hline $\mathrm{pH}_{1: 5}$ & \multirow{2}{*}{$\begin{array}{c}\text { soil water } \\
\text { suspension }\end{array}$} & $8 . .03$ & 8.04 \\
\hline $\mathrm{EC}_{1: 5}$ & & 1.62 & 2.06 \\
\hline Organic matter & $\%$ & 0.59 & 0.61 \\
\hline Total nitrogen & $\%$ & 0.029 & 0.031 \\
\hline AB-DTPA extractable P & $\mathrm{mg} \mathrm{kg}^{-1}$ & 2.77 & 2.52 \\
\hline AB-DTPA extractable K & $\mathrm{mg} \mathrm{kg}^{-1}$ & 124.8 & 130.3 \\
\hline
\end{tabular}

Weed whole plants NPK concentration (\%) and uptake $\left(\mathrm{kg} \mathrm{ha}^{-1}\right)$ under the influence of wheat fertilizer application rates

The changing fertilizer rates caused significant $(\mathrm{p}<0.05)$ fluctuation in weed whole plants N, P and K concentration (Fig. 1a, b) which were increased with increasing fertilizer rates. Among them, the application of 205-110-50 NPK kg ha' ${ }^{-1}$ recorded higher concentration of $\mathrm{N}(1.64 \%), \mathrm{P}(0.23 \%)$ and $\mathrm{K}(1.80 \%)$ in weed whole plants and were closely followed by fertilizer rate of 170100-50 kg NPK ha-1 that exhibited 1.54, 0.23 and $1.76 \% \mathrm{~N}, \mathrm{P}$ and $\mathrm{K}$ concentration in weed whole plants. However, without fertilizer application, the weed whole plants expressed minimum concentration of $\mathrm{N}$ $(0.98 \%), \mathrm{P}(0.08 \%)$ and $\mathrm{K}(1.03 \%)$ which demonstrate that the applied nutrients as inorganic chemical fertilizer increased weed crop competition leading to more flourishing of weeds on the expense of wheat crop.

Weed infestation in wheat crop under different fertilizer regimes increased weed crop competition for nutrients as shown by LSD test $(p \leq 0.05)$ that indicated significant differences for weed nutrients uptake (Fig. $2 \mathrm{a}, \mathrm{b})$. The figure illustrates that increasing fertilizer rates increased weed nutrient uptake. Among them, the higher fertilizer rate (205-110-50 $\mathrm{kg}$ NPK ha ${ }^{-1}$ ) recorded maximum weed uptake of $\mathrm{N}, \mathrm{P}$ and $\mathrm{K}$ $\left(101.15,14.36\right.$ and $\left.112.25 \mathrm{~kg} \mathrm{ha}^{-1}\right)$ followed by uptake of $90.08,13.62$ and 103.84 NPK $\mathrm{kg} \mathrm{ha}^{-1}$ when 170-100-50 kg NPK ha-1 were used. While, minimum weed $\mathrm{N}, \mathrm{P}$ and $\mathrm{K}$ uptake of 45.97, 3.67 and $48.68 \mathrm{~kg} \mathrm{ha}^{-1}$ was noted where no fertilizer applied. Statistically, weed's P and K uptake was at par from one another when higher fertilizer rates (170-100-50 and 205-110-50 kg NPK $\mathrm{ha}^{-1}$ ) were applied. It means that weed proliferation can be controlled through manipulation of applied nutrients and consequently weed crop competition is minimized.

Weed whole plants NPK concentration (\%) and uptake (kg ha-1) under the influence of irrigation frequencies

Irrigation plays an important role in crop production. In irrigated agriculture weeds are the main competitor of crop which competes with crop for space, moisture, nutrients and sun light. In an experiment, different irrigation frequencies were tested on wheat integrated with weed managements (data not provided) but in control plots where weeds infestation were allowed and the effect of irrigation frequencies were tested on weed whole nutrient concentration and uptake. The results showed significant differences for nutrient concentration $(\mathrm{N}, \mathrm{P}$ and $\mathrm{K})$ of weed 
whole plants across different irrigation frequencies (Fig. 3a, b). The maximum concentration of $\mathrm{N}(1.24 \%), \mathrm{P}(0.28 \%)$ and $\mathrm{K}(1.86 \%)$ were observed in plot where 6 irrigations were applied followed by 1.11 , 0.23 and $1.60 \%$ of $\mathrm{N}, \mathrm{P}$ and $\mathrm{K}$ when 5 irrigations were used. While, minimum $\mathrm{N}, \mathrm{P}$ and $\mathrm{K}$ concentration of $0.75,0.20$ and $1.04 \%$ was recorded where 3 irrigations were used. Similarly, the uptake of nutrients by weed whole plants also expressed significant differences across different irrigation regimes (Fig. 4a, b). The maximum uptake of $\mathrm{N}\left(70.83 \mathrm{~kg} \mathrm{ha}^{-1}\right), \mathrm{P}\left(15.89 \mathrm{~kg} \mathrm{ha}^{-1}\right)$ and $\mathrm{K}$ $\left(104.42 \mathrm{~kg} \mathrm{ha}^{-1}\right)$ were observed in plot when
6 irrigations were applied followed by 63.5 , 12.91 and $90.1 \mathrm{~kg} \mathrm{ha}^{-1}$ of $\mathrm{N}, \mathrm{P}$ and $\mathrm{K}$ when 5 irrigations were used. While, minimum N, P and $\mathrm{K}$ uptake of $27.03,7.19$ and $38.3 \mathrm{~kg} \mathrm{ha}^{-1}$ was recorded where 3 irrigations were applied. This demonstrate that weeds responded positively to irrigation frequencies under wheat crop and the uptake of nutrients by weed whole plants manifests the competition between weeds and wheat crop. When weeds were not controlled as in this case, wheat crop is suppressed due to competition for moisture and nutrients (Fig. $4 a, b)$.

Table 2. Effect of irrigation frequencies and NPK fertilizer rates on weed biomass ( $\left.\mathrm{kg} \mathrm{ha}^{-1}\right)$, weed density $\left(\mathrm{m}^{-2}\right)$ and weed frequency $(\%)$ in weedy plots under wheat crop

\begin{tabular}{|c|c|c|c|}
\hline & $\begin{array}{c}\text { Weed biomass } \\
\left(\mathbf{k g ~ h a}^{-1}\right)\end{array}$ & $\begin{array}{c}\text { Weed density } \\
\left(\mathbf{~ m}^{-2}\right)\end{array}$ & Weed frequency (\%) \\
\hline \multicolumn{4}{|c|}{ Irrigation frequencies } \\
\hline 3Irrigations & 3543.0 & 99.0 & 8.66 \\
\hline 4Irrigations & 4746.0 & 127.33 & 7.30 \\
\hline 5Irrigations & 5482.0 & 149.67 & 7.46 \\
\hline 6Irrigations & 5487.3 & 163.0 & 7.50 \\
\hline S.E & $\mathbf{2 0 1 . 2 1}$ & $\mathbf{3 . 0 0}$ & $\mathbf{0 . 7 0}$ \\
\hline LSD at 0.05 & $\mathbf{4 1 0 . 9 4}$ & $\mathbf{6 . 1 1}$ \\
\hline \multicolumn{5}{|c|}{ NPK Fertilizer rates $\left.\mathbf{( k g ~ h a}^{-1}\right)$} \\
\hline $0-0-0$ & 4563.0 & 96.33 & 5.17 \\
\hline 100-80-50 & 4630.0 & 107.33 & 5.93 \\
\hline 135-90-50 & 5262.3 & 143.00 & 6.13 \\
\hline 170-100-50 & 5578.7 & 156.00 & 6.50 \\
\hline 205-110-50 & 5916.7 & 166.67 & 6.50 \\
\hline S.E & $\mathbf{2 1 5 . 1 9}$ & $\mathbf{5 . 7 8}$ & $\mathbf{0 . 2 6}$ \\
\hline LSD at 0.05 & $\mathbf{4 3 5 . 6 2}$ & $\mathbf{1 1 . 6 9}$ & $\mathbf{0 . 5 3}$ \\
\hline
\end{tabular}

\section{Correlation}

Under the influence of irrigation frequencies, the extent of relationship as presented in (Fig.5a, b, c) revealed positive relationship between weeds biomass and weed whole plants $\mathrm{N}$ uptake $(\mathrm{r}=0.961), \mathrm{P}$ uptake $(r=0.968)$ and $K$ uptake $(r=0.930)$. Similarly, weed biomass also resulted in causing changes in weed uptake of $\mathrm{N}(92 \%)$, $\mathrm{P}(94 \%)$ and K (86\%) respectively. While a unit increase in weed biomass correspondingly increased weed nutrients uptake of $\mathrm{N}$ by $0.02 \mathrm{~kg} \mathrm{ha}^{-1}, \mathrm{P}$ by $0.004 \mathrm{~kg}$ $\mathrm{ha}^{-1}$ and $\mathrm{K}$ by $0.024 \mathrm{~kg} \mathrm{ha}^{-1}$. The student Test was performed on those parameters of weeds which had showed correlations and the calculated $\mathrm{T}$ value was examined for weed whole plants $\mathrm{N}$ uptake vs weed biomass (16.39), weed whole plants $\mathrm{P}$ utake vs weed biomass (15.33) and weed whole plants K uptake vs weed biomass (12.92). These $\mathrm{T}$ values were found higher than book 
value as calculated at $5 \%$ probability level which indicate that the correlations are highly significant.

Under the influence of NPK fertilizer application, the extent of relationship as presented in (Fig. 6a, b, c) revealed positive relationship between weed biomass and $\mathrm{N}$ uptake $(\mathrm{r}=0.91)$, $\mathrm{P}$ uptake $(\mathrm{r}=0.92)$ and $\mathrm{K}$ uptake $(r=0.90)$. Congruently, the variation in weed biomass also resulted in causing changes in weed whole plant uptake of $\mathrm{N}$ (92\%), P (94\%) and K (86\%). Whereas, a unit increase in weed biomass correspondingly increased weed whole plants nutrients uptake of $\mathrm{N}$ by $0.02 \mathrm{~kg} \mathrm{ha}^{-1}$, $\mathrm{P}$ by $0.005 \mathrm{~kg} \mathrm{ha}^{-1}$ and $\mathrm{K}$ by $0.03 \mathrm{~kg} \mathrm{ha}^{-1}$. The student Test was performed on those parameters of weeds which had showed correlations and the calculated $\mathrm{T}$ value was examined for weed whole plants $\mathrm{N}$ uptake vs weed biomass (16.29), weed whole plants $\mathrm{P}$ utake vs weed biomass (18.05) and weed whole plants $\mathrm{K}$ uptake vs weed biomass (15.89). These $\mathrm{T}$ values were found higher than book value as calculated at 5\% probability level which indicate that the correlations are highly significant.

\section{Discussion}

The results regarding weed traits included weed biomass, weed density and weed frequency under the influence of NPK fertilizer rates showed that the application of higher fertilizer rate (205-110-50 kg NPK $\mathrm{ha}^{-1}$ ) resulted in higher weed biomass, weed density and weed frequency. When fertilizer is added to the weed infested wheat crop where weeds are existing in higher densities, in this condition the applied fertilizer gave more benefits to weed at the cost of wheat because weeds were more competitor for nutrients than crop as reported by Carlson and Hill [26] who reported that the application of $\mathrm{N}$ fertilizer to wheat crop having weed infestation of wild oat revealed enhancement in density of wild oat and reduced wheat grain yield. But contradicting results were recorded by Tulikov and Sugrobov [27] and Mohammad et al. [28] that the application of N and NPK fertilizer to barley crop resulted in reducing weed dry weight and density. According to Scursoni and Arnold [29] that the higher $\mathrm{N}$ application rates in wheat crop when wild oat infestations were high resulted in wheat grain yield loss. Similar results were reported by Pourreza et al. [30] that $\mathrm{N}$ application enhanced the competitive ability of wild oat over wheat. Blackshaw et al. [11] and Ross and Van Acker [31] revealed that $\mathrm{N}$ application can stimulate seed dormancy of weed, so weed infestation increased and ultimately affected wheat grain yield. Blackshaw [32] examined the effect of $\mathrm{N}$ application on weed biomass and observed lower weed biomass in control where no fertilizer was applied while increasing fertilizer rates resulted in enhancing weed biomass. Most weeds in agricultural field give response to the applied $\mathrm{N}$ fertilizer to great extent as compared to main crop and the added $\mathrm{N}$ fertilizer is utilized effectively by weeds at the cost of crop [12]. The method of $\mathrm{N}$ application affect weed biomass and density as Blackshaw [32] observed higher weed biomass on surface applied $\mathrm{N}$ and lower at banded N. Conflicting results were reported by Ashrafi et al. [33] that medium fertilizer rate of $\mathrm{N}$ resulted in increased weed biomass but higher fertilizer rates suppressed weed biomass. The results of this study are supported by Acciaresi et al. [34] who examined that higher $\mathrm{N}$ rates resulted in increased growth of Lolium multiflorum aggressively over wheat. The study conducted by According to Abouziena et al. [35] that $\mathrm{N}$ contents of wheat grain was decreased by $2.7 \%$ due to weed infestation. It means that by changing the $\mathrm{P}$ fertility level of soil, weed crop competition can be minimized. 

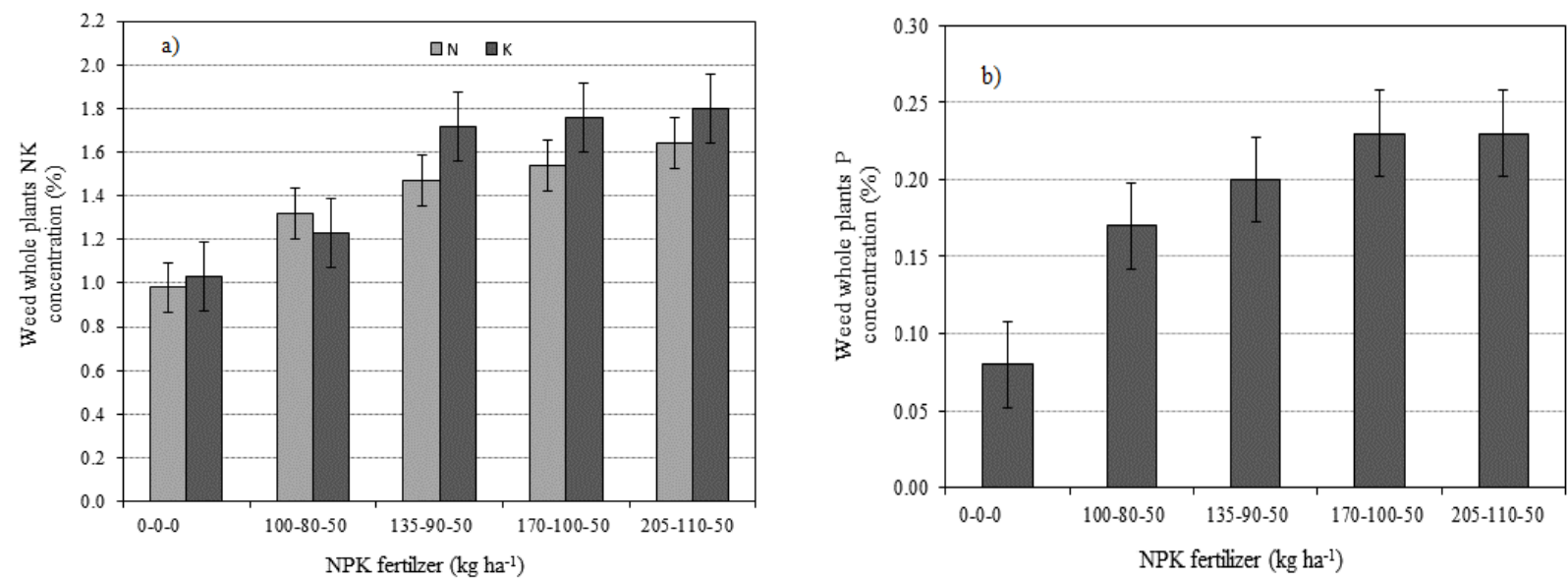

Figure 1. Effect of NPK fertilizer on weed whole plants $\mathrm{N}$ and $\mathrm{K}$ concentration (\%) (a) and $P$ concentration $(\%)(b)$
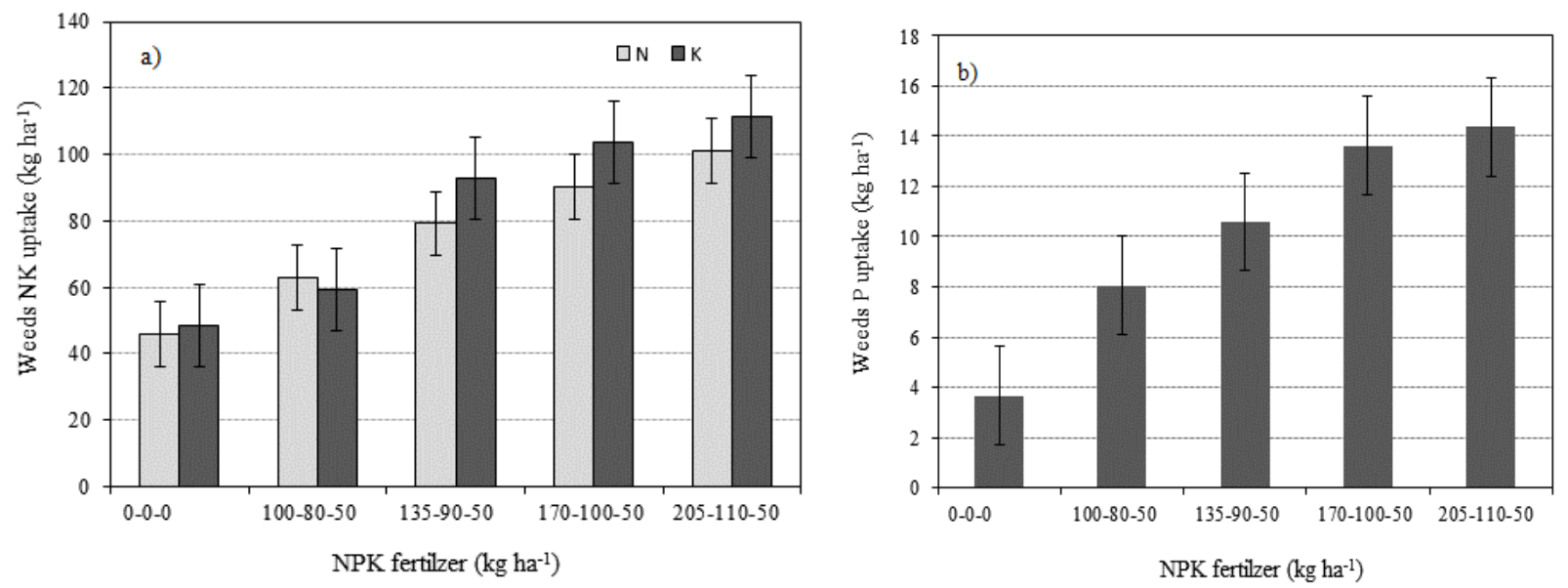

Figure 2. Effect of NPK fertilizer on weed $\mathrm{N}$ and $\mathrm{K}$ uptake ( $\left.\mathrm{kg} \mathrm{ha}^{-1}\right)$ (a) and P uptake (kg ha $\left.^{-1}\right)(\mathbf{b})$
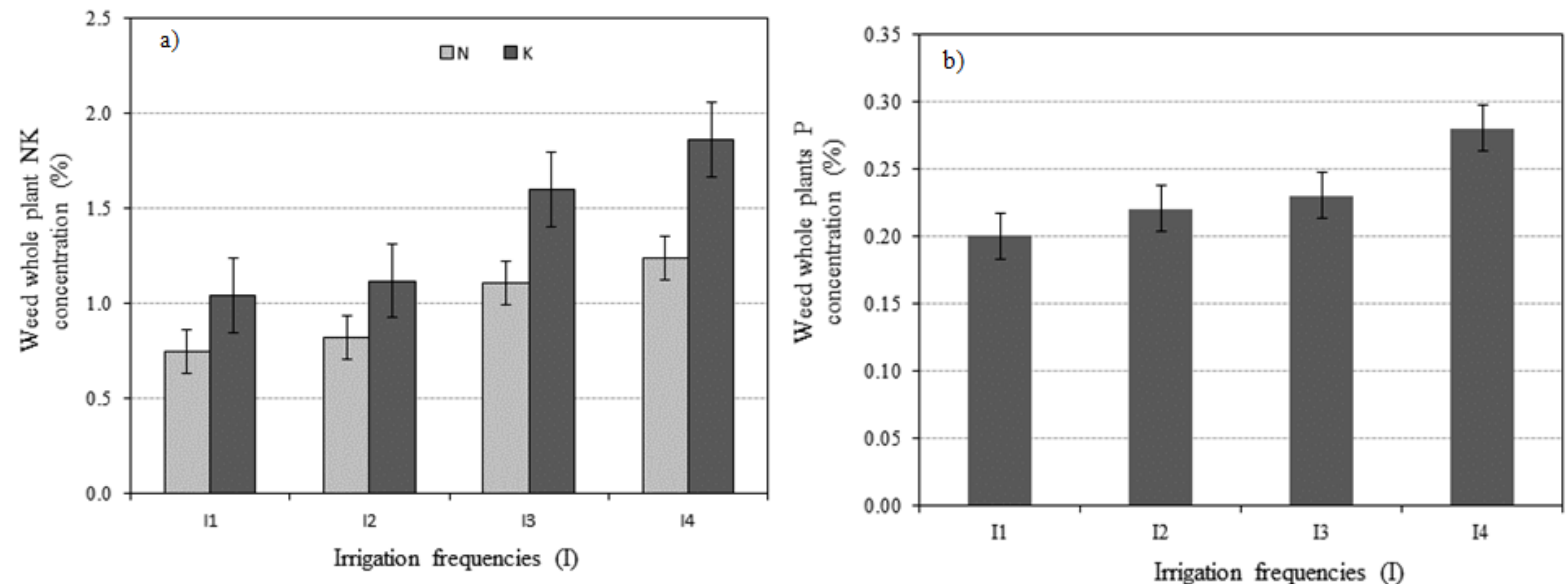

Figure 3. Effect of irrigation frequencies on weed whole plants $\mathbf{N}$, $\mathbf{K}$ concentration (a) and $P$ concentration $(b)$ 

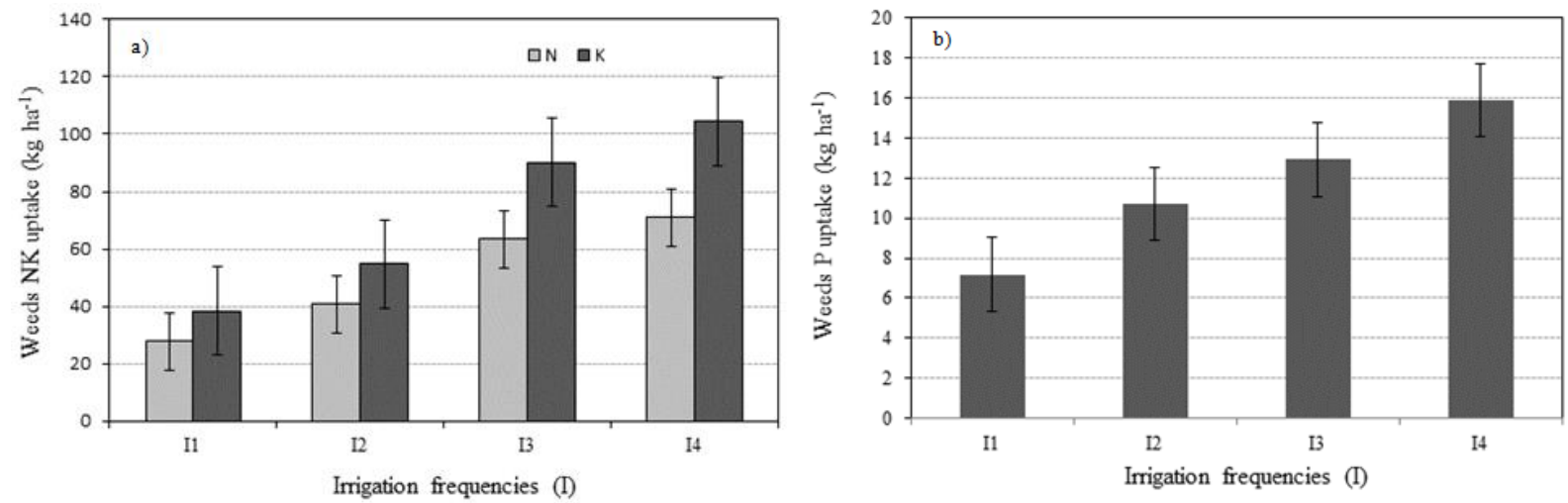

Figure 4. Effect of irrigation frequencies on weed N, K uptake (a) and P uptake (b)
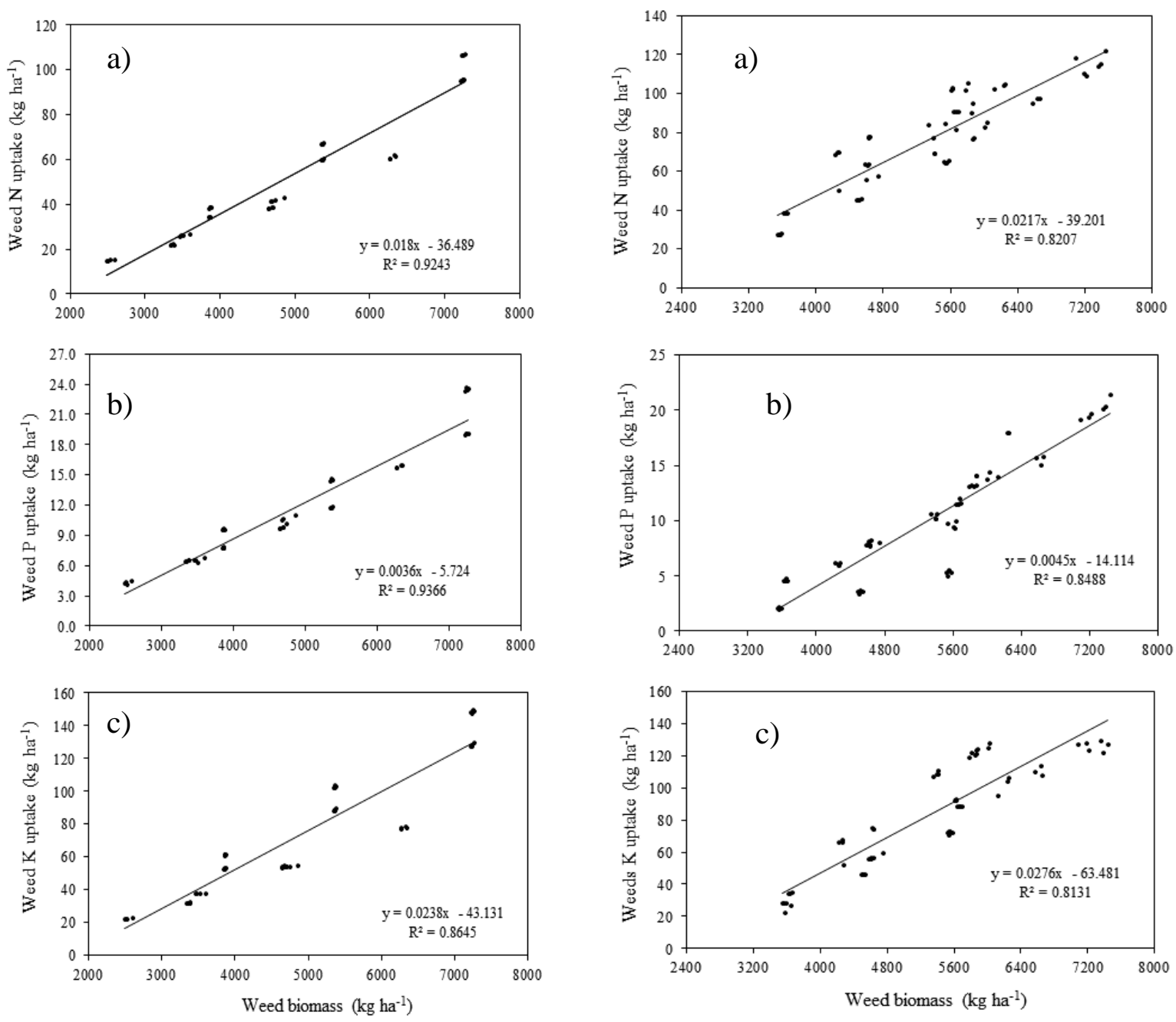

Figure 5. Linear regression between weed biomass and weed $\mathbf{N}$ uptake (a), $P$ uptake (b) and $K$ uptake (c) under the influence of irrigation frequencies

Figure 6. Linear regression between weed biomass and weed $\mathbf{N}$ uptake (a), $P$ uptake (b) and $K$ uptake (c) under the influence of NPK fertilizer rates 
The concluded statement of Dikici and Demet [36] manifested that weeds uptake equal or greater amount of nutrients over wheat crop. According to Lehoczky et al. $[37,38]$ that scientific background behind the occurrence of weed species is very important because it provides the basis for assessment of competitiveness of weeds over corp. Kalsoom et al. [39] reported that crop growth and dry matter is increased by the combined application of NPK rather than their alone application.

The results of Shahrajabian et al. [40] showed that grain $\mathrm{N}$ concentration of corn was decreased due to infestation of pigweed at the interactive effect of low irrigation $\mathrm{x}$ weeds presence. Infestation of pigweed may cause reduction in water availability as evidenced in work of Shahrajabian et al. [40] that the pigweed infestation resulted in decreased water availability which ultimately led to low $\mathrm{N}$ absorption by corn. However, higher irrigation frequency increased $\mathrm{N}$ uptake by corn at the expense of weed in term of decreasing the weed interference for $N$. While, Singh [41] recorded higher weed $\mathrm{N}, \mathrm{P}$ and $\mathrm{K}$ uptake in plot where weeds were allowed to grow. He explained that in this unweeded condition, weeds gain maximum dry matter by absorbing more nutrients. Kumar et al. [42] who revealed that $\mathrm{N}$ uptake by grain and straw was negatively associated to the $\mathrm{N}$ reduction by weeds.

\section{Conclusion}

From this study it was inferred that the application of higher fertilizer rate (205-110-50 $\mathrm{kg} \mathrm{NPK} \mathrm{ha}{ }^{-1}$ ) and higher irrigation frequency $\left(\mathrm{I}_{4}\right)$ resulted in higher weed biomass $\left(\mathrm{kg} \mathrm{ha}^{-1}\right)$, weed density $\left(\mathrm{m}^{-2}\right)$, weed frequency $(\%)$ leading to more nutrients uptake by weed plants. Consequently, the fertilizer added to the weed infested wheat crop with more number of irrigations gave more benefits to weed at the cost of wheat because weeds are more competitors for nutrients and moisture than crop. Authors' contributions
Conceived and designed the experiments: MA Babar, Performed the experiments: S Azam, Analyzed the data: A Khan \& M Arif, Contributed materials/ analysis/ tools: Ikramullah, Wrote the paper: MA Babarm \& S Hussain.

\section{References}

1. Hussain A, Ghaudhry MR, Wajad A, Ahmed A, Rafiq M, Brahim IM \& Goheer AR (2004). Influence of water stress on growth, yield and radiation use efficiency of various wheat cultivars. Inter J Agric Biol 6: 1074-1079.

2. Wajid A, Hussain A, Ahmed A, Rafiq M, Goheer AR \& Ibrahim M (2004). Effect of sowing date and plant density on growth, light interception and yield of wheat under semi-arid condition. Inter J Agric Biol 6: 1119-1123.

3. Shrief SA, Ashraf A \& Abd El-Mohsen (2015). Regression models to describe the influence of different irrigation regimes on grain yield and water use efficiency in bread wheat. Adv Agric Biol 4 (1): 39-49.

4. Ashraf M \& Harris PJC (2005). Abiotic stresses: Plant resistance through breeding and molecular approaches. Haward Press Inc., New York.

5. Foulkes MJ, Snape JW, Shearman VJ, Reynolds MP, Gaju O \& SylvesterBradley R (2007). Genetic progress in yield potential in wheat: recent advances and future prospect. J Agric Sci 145: 17-29.

6. Reynolds M, Foulkes MJ, Slafer G, Berry P, Parry MAJ, Snape JW \& Angus WJ (2009). Raising yield potential in wheat. $J$ Exp Bot 60: 18991918.

7. Tang L, Kaiyuan W, Chuanpeng C, Ruhai L, Daozhong W, Junfeng P, Yong T, Juan X \& Fang Chen C (2013). Effect of fertilization patterns on the assemblage of weed communities in an upland winter wheat field. J Plant Ecol $1-12$. 
8. El-Metwally IM, Abd El-Salam MS \& Tagour RMH (2010). Nitrogen fertilizer levels and some weed control treatments effects on barley and associated weeds. Agric Biol J N Am 1(5): 992-1000.

9. Poffenbarger HJ, Steven BM, Teasdale JR, Spargo JT, Cavigelli MA \& Matthew K (2015). Nitrogen Competition between Corn and Weeds in Soils under Organic and Conventional Management. Weed Sci 63(2):461-476.

10. Blackshaw RE \& Randall NB (2008). Nitrogen Fertilizer Rate Effects on Weed Competitiveness is Species Dependent. Weed Sci 56(5): 743-747.

11. Blackshaw RE, Molnar LJ \& Janzen HH (2004). Nitrogen fertilizer timing and application method affect weed growth and competition with spring wheat. Weed Sci 52: 614-622.

12. Blackshaw, R.E., N.B. Randall, H.J. Henryn, E. Toby, A.G. Cynthia and Douglas A. Derksen. 2003. Differential response of weed species to added nitrogen. Weed Sci 51(4):532-539.

13. Odum EP (1971). Fundamentals of Ecology, 3rd Edition, Saunders, Philadelphia. 574 pp.

14. Bouyoucos, G.J. 1962. Hydrometer method improved for making particlesize analysis of soils. Agron J 53:464465.

15. McKeague JA (Ed.) (1978). Manual on soil sampling and methods of analysis. Can Soc Soil Sci 66-68.

16. McLean EO (1982). Soil $\mathrm{pH}$ and lime requirement In: Page, A.L. (Ed.), Methods of soil analysis, Part 2: chemical and microbiological properties. Am Soc Agron, Madison, WI,USA, pp 199-224.

17. Walkley A (1947). A critical examination of rapid method for exterminating organic carbon in
soil:Effect of variations in digestion conditions and of organic soil constituents. Soil sci 63:251-263.

18. Black CA (1993). Soil fertility evaluation and control. Lewis publishers, Boca Raton, Florida, USA.

19. Sultan pour PN \& Schwab AP (Eds.) (1977). A new soil test for simultaneous extraction of macro-micro nutrients in alkaline soils. Commun Soil Sci plant Anal 8:195-207.

20. Jones JB (1991). Kjeldahl method for nitrogen determination. Micro-Macro Publishing Inc., Athens, GA, USA.

21. Sonneveld C \& Van Dijk PA (1982). The effectiveness of some washing procedures on the removal of contaminates from plant tissues of glass house crops. Commun Soil Sci plant Anal 13: 487-496.

22. Wolf B (1982). A comprehensive system of leaf analysis and its use for diagnosing crop nutrient status. Commun Soil Sci plant Anal 13: 10351059.

23. Cottenie A (1980). Soil and Plant testing as a basis of fertilizer recommendations. FAO soil Bulletin $38 / 2$.

24. Knudsen D, Peterson GA \& Pratt PF (1982). Lithium, sodium and potassium P. 225-245. In: A.L page (Ed.), Methods of Soil Analysis, Part 2: Chemical and microbiological properties. Am Soc Agron, Madison WI, USA.

25. Jones JB Jr (1991). Kjeldahl's method for nitrogen determination. MicroMacro Publishing Inc., Athens, GA, USA.

26. Carlson HL \& Hill JE (1986). Wild oat (Avena fatua) competition with spring wheat: Effects of nitrogen fertilization. Weed Sci 34: 29-33.

27. Tulikov AM \& Sugrobov VM (1984). Role of long-term application of 
fertilizer, lime and crop rotation in change of infestation in field by weeds. Izvestia TCXA 2: 32-36.

28. Mohammad DHR, Tulikov AM \& Baghestani MA (2006). Effect of Longterm fertilizer application and crop rotation on the infestation of fields by weed. Pak J Weed Sci Res 12 (3):221234.

29. Scursoni AJ \& Arnold RB (2002). Effect of nitrogen fertilization timing on the demographic processes of wild oat (Avena fatua) in barley (Hordeum vulgare). Weed Sci 50: 616-621.

30. Pourreza J, Bahrani A \& Karami S (2010). Effect of nitrogen fertilization application on stimulating wheat (Triticum aestivum) yield loss caused by wild oat (Avena fatua) interference. American-Eurasian J Agric Environ Sci 9(1):55-61.

31. Ross DM \& Van Acker RC (2005). Effect of nitrogen fertilizer and landscape position on wild oat (Avena fatua) interference in spring wheat. Weed Sci 53:869-876.

32. Blackshaw RE (2005). Nitrogen fertilizer, manure and compost effects on weed growth and competition with spring wheat. Agronomy J 97:16121621.

33. Ashrafi ZY, Alizade HM, Mashhadi HR \& Sadeghi S (2010). Study effect of tillage, herbicide and fertilizer rates on wheat (Triticum aestivum) and weed populations, in Iran. Bulg. J Agric Sci 16: 59-65.

34. Acciaresi HA, Chidichimo HO \& Sarandon SJ (2001). Wheat-Lolium multiflorum competition: effect of nitrogen application onto Argentinean varieties aggressivity. Cereal Res Comm 29:451-458.
35. Abouziena HF, Sharara Faida AA \& Eldesoki ER (2008). Efficacy of cultivar selectivity and weed control treatments on wheat yield and associated weeds in sandy soils. World J Agric Sci 4(3):384389.

36. Dikici H \& Demet GD (2006). Wheatweed competition for nutrients in Kahramanmaras, Turkey. Pak J Biol Sci 9(3):341-344.

37. Lehoczky É et al. (2012). Effect of different fertilization methods and nitrogen doses on the weediness of winter wheat. Commun Soil Sci plant Anal 43(1-2):341-345.

38. Lehoczky É, Kismányoky A \& Németh $\mathrm{T}$ (2013). Effects of nutrient supply and soil tillage on the weeds in maize. Commun Soil Sci plant Anal 44(14):546-550.

39. Kalsoom UE et al. (2012). Response of maize and three perennial weeds to different combinations of macronutrients. Pak J Weed Sci Res 18 (4):433-443.

40. Shahrajabian MH, Xuzhang X, Ali S, Peter OO \& Yuegao H (2013). Evaluation of physiological indices of winter wheat under different irrigation treatments using weighing lysimeter. Inter J Farm Alli Sci 2(24):1192-1197.

41. Singh AJ (2012). Weed management in irrigated wheat (Triticum aestivum) with special reference to buttercup weed (Ranunculus spp) in north-west Himalayas. Ind J Agric Sci 82(8): 706710.

42. Kumar N, Mina BL, Singh KP, Chandra S, Kumar M \& Srivastva AK (2010). Weed control for yield and profit maximization in wheat (Triticum aestivum) in Indian Himalayas. Ind $J$ Agron 55 (2):119-22. 